\title{
Childhood Hearing Health: Educating for Prevention of Hearing Loss
}

\author{
Adriana Bender Moreira Lacerda ${ }^{1}$ Claudia Giglio de Oliveira Gonçalves ${ }^{2}$ Giselle Lacerda ${ }^{1}$ \\ Diolén Conceição Barros Lobato ${ }^{1}$ Luciana Santos ${ }^{1}$ Aline Carlezzo Moreira ${ }^{1}$ Angela Ribas ${ }^{2}$ \\ 1 Universidade Tuiuti do Paraná, Curitiba, PR, Brazil \\ 2 Programa de Mestrado e Doutorado em Distúrbios da Comunicação \\ da Universdidade Tuiuti do Paraná, Curitiba, PR, Brazil \\ Address for correspondence Angela Ribas, PhD, Programa de \\ Mestrado e Doutorado em Distúrbios da Comunicação da \\ Universdidade Tuiuti do Paraná, Rua Jose Isidoro Biazetto 845 Curitiba, \\ PR 81200240, Brazil (e-mail: angela.ribas@utp.br).
}

Int Arch Otorhinolaryngol 2015;19:16-21.

\begin{abstract}
Keywords

- hearing loss

- public health

- schools

- noise

- audiology

Introduction The presence of noise in our society has attracted the attention of health professionals, including speech-language pathologists, who have been charged along with educators with developing hearing conservation programs in schools.

Objective To describe the results of three strategies for awareness and hearing preservation in first to fourth grades in public elementary schools.

Methods The level of environmental noise in classrooms was assessed, and 638 elementary school students from first to fourth grades, 5 to 10 years of age, were audiologically evaluated. After the evaluations, educational activities were presented to children and educators.

Results The noise level in the classroom ranged from 71.8 to 94.8 A-weighted decibels. The environment of the classroom was found to promote sound reverberation, which hinders communication. Thirty-two students (5.1\%) presented hearing alterations.

Conclusion The application of strategies for a hearing conservation program at the school showed that noise is present in the room, and hearing loss, sometimes silent, affects schoolchildren. Students and teachers were aware that hearing problems can be prevented. Avoiding exposure to noise and improving the acoustics in classrooms are essential.
\end{abstract}

\section{Introduction}

The scientific community is aware of the problems caused by noise in classrooms, and the need for early diagnosis of hearing disorders in schoolchildren has been assessed in studies that address this topic. In the United States, for four decades, children's hearing has been screened in school for the identification and referral of cases of hearing loss that interferes with learning. ${ }^{1,2}$

Despite the consensus among professionals about the importance of implementing hearing conservation programs in school, there are still few such initiatives in Brazil. Noise is assessed in classrooms and hearing screenings are performed to identify students with hearing impairments, but preventive actions are not introduced. ${ }^{3}$

Work in the field of psychiatry shows that the perception that something is good or bad and the change of behavior toward a hazard depends on the level of insight created by the subject. ${ }^{4}$ Something can be learned in the classrooms and reach intellectual level of insight without causing any behavioral changes; however, when what was taught reaches the emotional insight, learning occurs and behavior is changed. As an example, in the area of hearing health, ${ }^{5}$ we can assert that children, youths, and adults are aware that noise is received

February 18, 2014 accepted after revision July 7, 2014

published online

September 3, 2014
DOI http://dx.doi.org/

10.1055/s-0034-1387810. ISSN 1809-9777.
Copyright $\odot 2015$ by Thieme Publicações License terms

Ltda, Rio de Janeiro, Brazil

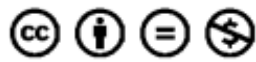


harmful to their health. They are able even to mention the hazards that noise can cause to hearing and the body in general, but few people avoid being exposed to noise, especially when it is related to pleasure and leisure activities. This fact allows us to infer that the knowledge acquired on the subject was not able to promote behavioral change, in other words, did not generate emotional insight.

Aware of this reality, some organizations and international institutions have turned their attention to the necessity of preventing hearing alterations due to noise. ${ }^{6}$ This is the case of the campaign launched in the United States called "Dangerous Decibels," which aims to reduce the incidence and prevalence of noise-induced hearing loss and tinnitus in school-aged children through educational measures on the auditory behaviors of children, parents, and teachers regarding hearing health promotion. ${ }^{5-7}$

The implementation of a hearing conservation program should focus on three aspects: the evaluation and study of the school environment, auditory profile identification of the children, and educational activities on awareness for children, parents, and teachers about the importance of early detection of hearing loss. ${ }^{5-7}$

An important aspect when considering a hearing conservation program at the school is noise. Several studies have indicated high levels of noise in school settings. These studies have found noise levels ranging from 59.5 to 94.3 A-weighted decibels $[\mathrm{dB}(\mathrm{A})]$, mainly in the front of the classroom, which is where the teacher normally is. ${ }^{8-11}$ However, the Brazilian Norm 10152/2000 (Noise Level for Acoustic Comfort), which deals with noise levels for acoustic comfort, indicates $45 \mathrm{~dB}$ (A) as the maximum acceptable level of noise in a classroom. ${ }^{12}$

The task of listening to a teacher's voice can be jeopardized at school when the intensity is not suited to the acoustics of the classroom. Excessive noise generated inside or outside the classroom can mask the teacher's speech, making it difficult for students to understand and concentrate. ${ }^{13}$ Besides this negative impact on communication in the classroom, continuous noise in excess, even if it is not enough to cause hearing loss, can cause symptoms such as fatigue, difficulty concentrating, low performance, stress, headaches, and irritability for both the teachers and the students. ${ }^{4,10}$

Another important aspect of hearing assessment at school should be the identification and treatment of hearing disorders. A common cause of hearing alterations for school-aged children found in studies is otitis media, characterized by inflammation in the middle ear accompanied (or not) by secretion, and it may be acute or chronic, leading to mild to moderate hearing loss. This change often goes unnoticed in childhood by parents or educators and leads to impairment not only of communication but also of the potential for expressive and receptive language and literacy, as well as social and emotional development, interfering in school learning. ${ }^{3,14}$

Another cause of hearing disorders in school-aged children is nonoccupational noise-induced hearing loss caused by exposure to high sound pressure levels, especially the frequent use of portable electronic devices, leading to temporary or permanent hearing loss. ${ }^{5,15}$ It is important to point out that early exposure to high sound pressure levels can result in increased susceptibility to auditory alterations as an adult. $^{16}$

Reflecting on these issues, the National Policy on Hearing Health Care-PNASA (ORDINANCE 2.073/GM on September 28, 2004) was established in Brazil, allowing the development of actions to promote quality of life and health education, as well as the protection and recovery of health. In Article 3, PNASA defines the following as actions of hearing health primary care: conduction of individual or collective actions dedicated to hearing health promotion, prevention and early identification of hearing problems, and providing specific, informative, educational, and family-oriented actions. Health care units specializing in problems from medium to high complexity must have multidisciplinary teams for hearing screening (including for preschool and elementary-level children) for clinical and therapeutic treatment, as well as providing hearing aids when necessary. ${ }^{17}$

Complementing these issues, in 2007, a School Health Program-PSE (Decree 6286 of December 5, 2007) was established with the goal of contributing to the integral education of public primary education students in the prevention of health problems and promotion and attention to health care. In planning PSE actions, the social context of the school, onsite school health diagnosis, and operative capacity for school health must be considered. Among the actions planned in the PSE are hearing evaluations and the promotion of a culture of prevention in schools. $^{18}$

Some studies report that $\sim 80 \%$ of school-aged children suffer at least temporary hearing loss during the school year. This hearing loss is not perceived by the child as abnormal and, on that basis, it is not reported to family or school officials, preventing its detection. Thus, we highlight the importance of early diagnosis, allowing the family to receive guidance from an interdisciplinary team regarding the program for prevention of hearing loss in schools. ${ }^{19-21}$

Another issue that deserves mention is educational activities promoting awareness that are aimed at children, parents, and teachers. Educational activities should contain information on causes and effects of hearing loss in the population involved, diagnosis of hearing loss in schools, assessment of the effects of hearing loss on communication and learning, habilitation and rehabilitation of cases with hearing disorders, and monitoring children with disorders. The activities can be performed through educational measures involving activities such as research on the topic, the preparation of posters, use of informational videos, and student writing assignments. In addition, information can be provided for parents and the community in general, as well as minicourses, guidance, and advice about auditory health. 2,5,22

The aim of this study is to describe the result of strategies for awareness and hearing conservation in first to fourth grades of public elementary school.

\section{Methods}

This is a cross-sectional study involving two public elementary school schools in the city of Curitiba in the state of 
Table 1 Noise intensity present in classrooms

\begin{tabular}{|l|l|l|l|l|l|l|}
\hline Location & \multicolumn{2}{|l|}{ Near teacher } & Near window & \multicolumn{2}{l|}{ Opposite window } \\
\hline & Minimum (dB) & Maximum (dB) & Minimum (dB) & Maximum (dB) & Minimum (dB) & Maximum (dB) \\
\hline Room A & 71.3 & 80.8 & 75.1 & 89.5 & 71.8 & 85.7 \\
\hline Room B & 72.6 & 81.9 & 77.6 & 94.8 & 70.4 & 81.9 \\
\hline Room C & 78.5 & 83.7 & 73.9 & 91.6 & 74.1 & 84.2 \\
\hline
\end{tabular}

Parana. The schools are located in residential neighborhoods considered middle class.

Two strategies of evaluation were performed: environmental noise levels in classrooms were measured and hearing assessed in the students, and awareness programs were presented to students and teachers. Assessment strategies aimed to verify the environmental or students' hearing conditions and also to support educational activities and to generate reflection.

To measure environmental noise, sound intensity levels present in three classrooms were evaluated using a Bruel \& Kjaer model 2230 (Bruel \& Kjaer - Denmark) sound-level meter. Three positions were measured for sound pressure levels using instant readings (curve A-hearing level): near the teacher, near the window, and opposite the window. The presence of noisy equipment in classrooms, window positions, the position of the room in relation to the school, and acoustical materials or coverings used in the rooms were registered.

Hearing evaluation was performed in 638 children, ranging in age from 5 to 10 years. All students underwent an otoscopy to verify the absence of obstruction in the ear canal. Soon after, the students were given conventional pure tone audiometry in a soundproof booth, located in a quiet room in the school. The equipment used was Maico MA41 (Medical Acoustic Instrument Company - USA). Hearing thresholds less than or equal to 20-dB hearing level were considered to be normal. Children with abnormal auditory thresholds were referred for medical consultation with an ear, nose, and throat specialist.

After carrying out the evaluations, the results were presented to students and teachers with the intention of raising awareness of noise levels present in the school environment, the number of children with hearing alterations, and the relation between noise and hearing health. Educational actions were adopted as follows. An interactive dialogue, 30 minutes long for each class, was used. Multimedia projectors with a slide presentation were used, and an educational coloring book was distributed that covered the following topics: the importance of hearing, how the auditory system works, necessary care for hearing, and mechanisms to compensate for deafness. This material was provided by a hearing aid company that lectures on hearing health in schools nationwide through the project "Forward Pass." Teachers participated in exhibitions and were asked to include the content covered in their classes.

The collected data were analyzed qualitatively and quantitatively. This study was approved by the Ethics Committee at the Hospital de Clinicas under registration number CAAE 0214.0.208.000-11.

\section{Results}

The noise level was formally assessed in three classrooms, at three positions in the rooms: near the teacher, near the window, and opposite the window (-Table 1). The three available rooms had fans; the windows were open, had opened fabric curtains, and faced the athletic courts; and the floor was granite. Sound intensity levels in school were high. Registered intensities ranged from $71.3 \mathrm{~dB}(\mathrm{~A})$ to $83.7 \mathrm{~dB}$ (A) near the teacher, $75.1 \mathrm{~dB}(\mathrm{~A})$ to $94.8 \mathrm{~dB}(\mathrm{~A})$ near the window, and $71.8 \mathrm{~dB}(\mathrm{~A})$ to $85.7 \mathrm{~dB}(\mathrm{~A})$ opposite the window.

A total of 638 students between 5 and 10 years of age (first to fourth grades of primary school) had audiologic evaluations; 320 (50.1\%) were boys and 318 (49.9\%) were girls (-Table 2). Of the 638 students tested, 32 presented alterations (5.1\%). In abnormal tests, conductive hearing loss, high-frequency hearing loss, and sensorineural hearing loss were observed (-Fig. 1). Of the five children with sensorineural hearing loss, three wore hearing aids.

There was a higher percentage of abnormal tests at the age of 6 years (-Table 3 ). There was a higher percentage of hearing impairment in boys, with a prevalence of hearing loss in high frequencies (-Figs. 2 and $\mathbf{3}$ ).

As previously mentioned, the data obtained from the environmental and auditory evaluations were used as a resource to illustrate the hazards of noise in the school environment during educational actions.

Students and teachers from both schools attended minilectures, where researchers led a dialogue exhibition on hearing functioning and preserving hearing quality. After being sensitized, children identified sources of noise in school and made a list with several strategies to minimize environmental noise and its effects: not shouting in the schoolyard

Table 2 Sample by gender and age group

\begin{tabular}{|l|l|l|}
\hline Age (y) & Gender & Male \\
\hline & Female & 11 \\
\hline 5 & 10 & 79 \\
\hline 6 & 60 & 61 \\
\hline 7 & 59 & 60 \\
\hline 8 & 72 & 65 \\
\hline 9 & 69 & 42 \\
\hline 10 & 50 & 318 \\
\hline Total & 320 & \\
\hline
\end{tabular}




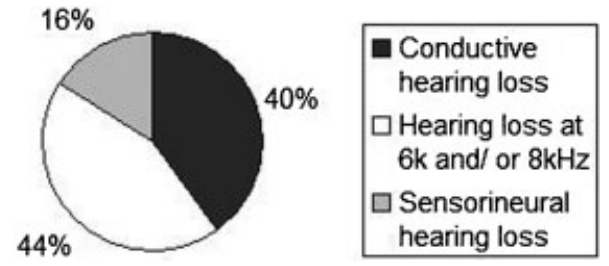

Fig. 1 Classification of hearing impairments $(n=32)$.

during recess and physical education; avoiding unnecessary talking in the classroom; using equipment such as televisions, computers, and video games at appropriate volumes; avoiding noisy places.

After completing the educational activities, teachers evaluated the dynamics used, the material presented, and the children's attitude before the topic discussed. In a feedback meeting with the researchers, teachers reported that the dynamics used by the researchers was positive and effectively impacted the behavior of the educational agents involved (teachers, coordinators, teacher assistants); the material used in the meetings with children was relevant; the theme recurred among children from the classrooms that participated in the activities proposed, which showed internalization of contents worked. All teachers understood the importance and relevance of the topic.

\section{Discussion}

Assessment of environmental noise measurement of sound intensity level in school showed that noise levels are high, above recommendations laid out in NBR $10.152,{ }^{12}$ which calls for a sound comfort level of $35 \mathrm{~dB}(\mathrm{~A})$ and an acceptable level of $50 \mathrm{~dB}(\mathrm{~A})$. These levels were also corroborated in the findings of other authors who reviewed the noise in three classrooms and obtained maximums of 84.3, 96.2, and $93 \mathrm{~dB}$ (A) and minimums of $66.1,71.1$, and $67.4 \mathrm{~dB}(\mathrm{~A})$; the authors noted the three evaluated rooms were above the level of $50 \mathrm{~dB}(\mathrm{~A}) .{ }^{23}$ Other authors measured noise levels in accordance with ANSI standards in seven classrooms from five schools in the municipal schools in the city of Urussanga in the state of Santa Catarina, where noise levels present in the classrooms ranged from 59.5 to $71.3 \mathrm{~dB}(\mathrm{~A}) .{ }^{11}$ However, values did not quite reach the levels from other studies that found peak values exceeded $100 \mathrm{~dB}(\mathrm{~A}){ }^{24}$ Therefore, it is important to emphasize that we need to be judicious in these measurements, because the noise levels below $85 \mathrm{~dB}$ are not considered harmful to hearing health but may compromise educational learning and development. ${ }^{25}$

In the school context, it is essential that the speech-language pathologist acts as a member of the educational team, recommending the necessary classroom environment changes, analyzing noise and acoustics in the classroom, and establishing educational programs for children about the auditory system and the dangers of noise at high intensities. To reduce the noise level, we recommend the planting of trees and shrubs around the school, as they buffer sound; the use of double-glazed windows; and carpeting on classroom floors and corridors to decrease the sounds made by moving people. ${ }^{4}$

For future research, it is important that noise assessment in all school environments include assessment of the presence of noise-absorbing materials, noisy materials, coverings, and even the teacher's voice. This will describe the school environment in an integral way, and not just the school noise.

Hearing assessments results indicated that of the 638 students who underwent audiometry, 32 (5.1\%) showed hearing impairment. This study found lower percentages of hearing disorders than other studies, which found variations from 24 to $29 \%$ of alterations in screening tests. ${ }^{3,20,26}$ In this study, there were more hearing disorders in boys, with a statistically significant difference. This study, however, gave different results from other studies of schoolchildren, which found no significant difference between genders. Auditory alterations were found mostly in children under 6 years of age (-Table 2), precisely the period in which children are starting the process of literacy, when sensory alterations may end up jeopardizing the entire learning process. ${ }^{27,28}$

In abnormal exams, three types of hearing loss were found: sensorineural (15.6\%), conductive (40.6\%), and hearing loss at frequencies of 6000 and/or $8000 \mathrm{~Hz}$ (43.7\%). Of the five reported cases of sensorineural hearing loss, three students were hearing aid users with moderate to severe degree of hearing loss, and two students were classified as mild to moderate degree loss that had not been previously diagnosed.

Table 3 Audiometry results by age group $(n=638)$

\begin{tabular}{|l|l|l|l|l|l|}
\hline Age $(\mathrm{y})$ & \multicolumn{2}{l|}{ Normal hearing } & \multicolumn{2}{l|}{ Altered hearing } & \multirow{2}{*}{ Number of students } \\
\hline & $\boldsymbol{n}$ & $\%$ & $\boldsymbol{n}$ & $\%$ & \\
\hline 5 & 20 & 90.9 & 2 & 9.1 & 22 \\
\hline 6 & 125 & 90.5 & 13 & 9.5 & 138 \\
\hline 7 & 117 & 98.3 & 2 & 1.7 & 119 \\
\hline 8 & 128 & 95.5 & 6 & 4.5 & 134 \\
\hline 9 & 129 & 96.9 & 4 & 3.1 & 133 \\
\hline 10 & 87 & 94.5 & 5 & 5.5 & 92 \\
\hline Total & 606 & 94.9 & 32 & 5.1 & 638 \\
\hline
\end{tabular}




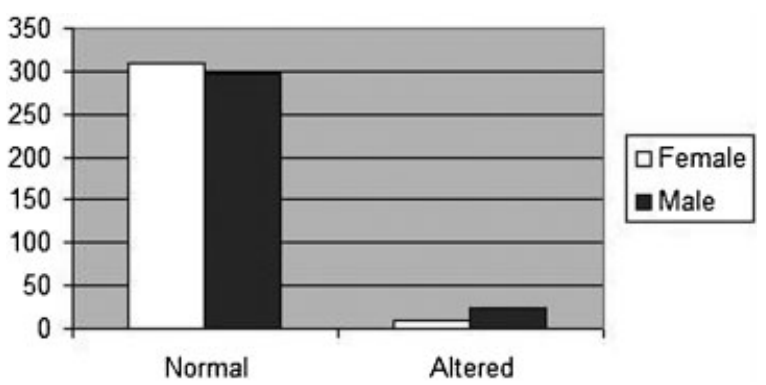

Fig. 2 Classification of audiometric results by gender $(n=638)$.

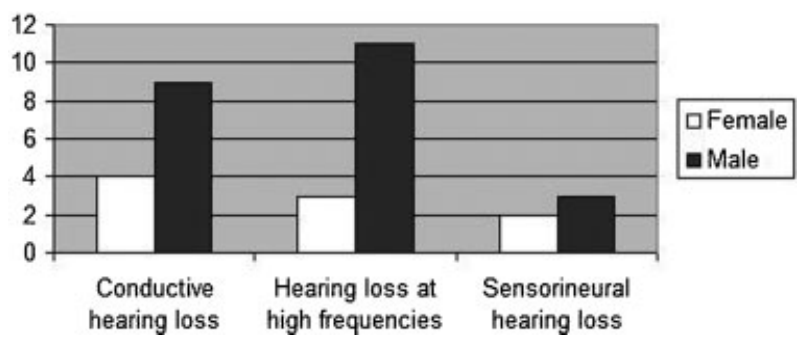

Fig. 3 Classification of hearing impairments by gender $(n=32)$.

An early diagnosis of sensorineural hearing loss enables better school performance and integration of the child into society. This, together with hearing rehabilitation, becomes less expensive and laborious for the health care area (family, government). ${ }^{13,29,30}$

The rate of conductive hearing loss corroborates other studies that also found a high rate of middle ear alterations in school-aged children. ${ }^{3,28}$ Conductive hearing loss may go unnoticed in childhood and compromise many aspects of the child's life, interfering negatively in school learning. So it must be detected promptly and treated properly by a specialist. ${ }^{3,14}$

Auditory alterations in the frequencies of 6000 and/or $8000 \mathrm{~Hz}$ found in this study agree with other studies that place this type of hearing impairment as the main characteristic of hearing loss induced by nonoccupational noise, mainly caused by exposure to loud noises like the use of portable electronic devices played at a high volume, as well as excessive noise from toys and electronic games. ${ }^{6,15}$ Hearing loss in frequencies of 6000 and $8000 \mathrm{~Hz}$, considered high frequencies, may also go unrecognized. ${ }^{29}$ These alterations are irreversible and impair speech intelligibility, as they undercut the process of auditory discrimination. ${ }^{30}$

There are few studies on noise-induced hearing loss in children. It is known, however, that young people have increased exposure to loud noises in their leisure activities, such as the use of personal listening devices and noisy toys. These early exposures can cause permanent damage to the inner ear, resulting in irreversible hearing loss. ${ }^{15,31}$

We know ultimately that school hearing screening is crucial for early detection of hearing disorders, enabling referrals to professionals to solve the problems encountered and prevent learning difficulties that may occur due to hearing problems. ${ }^{20}$

The data regarding the noise levels in classrooms and incidence of hearing loss in school were used, along with the educational actions, with the aim of sensitizing students and teachers about the importance of hearing health promotion, following the provisions by Kaplan and Sadock. ${ }^{4}$ The goal was to make clear, in a constructive and informal manner, the importance of avoiding exposure to noise and periodically evaluating hearing, with a view to promoting hearing health.

The use of fun materials with accessible language is necessary in educational activities so that the content is understood and can effect changes in the audience. Educational activities should be diversified according to the age of the children, using teaching materials and relaxed conversation. Included in this action was information not only about the mechanisms of hearing loss but also about the necessary changes in the school environment to facilitate learning. ${ }^{6}$

Research indicates that the earlier and more repeatedly these education experiences happen, the more effective the message received by the public. Among students, this measure has been quite effective. However, little has been done to raise awareness of children about the hearing damage that noise can cause. The "Dangerous Decibels" campaign is an example of a program that uses educational activities to bring this awareness to children and young Americans. ${ }^{1,22}$

The present research educated children, leading them to improve their understanding about hearing care, and also sought to sensitize the teachers involved in the proposed activities, as they are opinion makers. Multiple evaluations of nature have always lived side by side in the communities, ${ }^{32}$ depending on the sociocultural context and history of the people. These differences ultimately influence the values we set, including those that constitute a problem. The perception of a problem will depend on the culturally variable expectations regarding negative expectations, and many are already instilled values in society. ${ }^{33}$ In this study, both students and teachers identified noise as a negative factor in the school and identified strategies to minimize their effects. According to Giddens, ${ }^{34}$ information about a particular risk may cause people to reflect on the activity, which could result in changing their behavior.

The hearing conservation program in schools seeks to avoid future difficulties in the child's communication and social life. This can be achieved with the prevention of problems that might harm the child's development as a whole, giving children the opportunity to learn and develop properly to reach adulthood with greater potential. This is possible not only through screening, but also with actions to raise awareness in children, parents, and teachers about noise and hearing health care. ${ }^{26}$

The professionals involved in these actions contribute not only their expertise in the field of audiology, acoustics, and language, but also their knowledge and the ability to develop programs to raise awareness in children who, in learning early to value their hearing, can change behavior and protect their hearing as they grow. These professionals can contribute to improving the school environment. ${ }^{4}$

More studies like this should be performed not only to prevent children and young people from impairing their hearing but also to enhance professional knowledge regarding hearing conservation. The study allowed us to emphasize 
that it is important for the audiologist to act as a member of the educational staff to recommend the necessary classroom environment changes, thus promoting hearing health for the school community, and it is also important to establish prevention programs that include discussions about the dangers of high noise intensities and other hearing care issues to avoid temporary and permanent hearing loss.

\section{Conclusion}

The noise level in classrooms ranging between 71.8 and $94.8 \mathrm{~dB}(\mathrm{~A})$ were reported as intense. In this sample, we found 32 students (5.1\%) who had some type of hearing impairment. The most frequent alteration was hearing loss in frequencies of 6000 and/or $8000 \mathrm{~Hz}$, which was present in 14 of $32(43.7 \%)$ children with hearing impairment. Children actively participated in the activities proposed after being sensitized by the results of assessments. Teachers understood the proposal of the actions and could identify in their students positive behaviors toward hearing health.

\section{References}

1 Martin WH. Dangerous decibels: partnership for preventing noise-induced hearing loss and tinnitus in children. Semin Hear 2008;29(1):102-110

2 Griest S. Evaluation of a hearing-loss prevention program. Semin Hear 2008;29(1):122-135

3 Dreossi RCF, Momenshon-Santos T. O Ruído e sua interferência sobre estudantes em uma sala de aula: revisão de literatura. Rev Pró-Fono 2005;17(2):251-258

4 Kaplan HI, Sadock BJ. Compêndio de psiquiatria: ciências do comportamento e psiquiatria clínica. Porto Alegre, Brazil: Artes Médicas; 1997

5 Ribas A. Reflexões sobre o ambiente sonoro da cidade de Curitiba: a percepção do ruído urbano e seus efeitos sobre a qualidade de vida de moradores dos Setores Especiais Estruturais [Tese]. Curitiba, Brazil: UFPR; 2007

6 Serra MRB, Biassoni EC, Hinalaf M, et al. Program for the conservation and promotion of hearing among adolescents. Am J Audiol 2007;16(2):S158-S164

7 Lacerda ABM. Audição no contexto da educação: práticas voltadas a promoção e a prevenção. In: Bevilacqua MC, Martinez MAN, Balem AS, Pupo AC, Reis ACMB, Frota S., (orgs). Tratado de Audiologia. São Paulo, Brazil: Editora Santos; 2011:549-568

8. Oiticica MLGR, Gomes MLMB. O estresse do professor acentuado pela precariedade das condições acústicas das salas de aula. XXIV Encontro Nacional de Engenharia de Produção, 03-05 nov 2004, Florianópolis, Brazil: UFSC; 2004

9 Klodzinki D, Arnas F, Ribas A. O ruído em salas de aula de Curitiba: como os alunos percebem este problema. Rev Psicopedagogia. 2005;22(1):105-110

10 Libardi A, Gonçalves CGO, Vieira TPG, Silvério KCA, Rossi D, Penteado RZ. O ruído em sala de aula e a percepção dos professores de uma escola de ensino fundamental de Piracicaba. Rev Dist Comunicação. 2006;18(2):167-178

11 Jaroszewski GC, Zeigelboim BS, Lacerda ABM. Ruído escolar e sua implicação na atividade de ditado. Rev CEFAC. 2007;9(1):122-132
12 ABNT. Associação Brasileira de Normas Técnicas. NBR 10152:2000 -Acústica-Avaliação do ruído ambiente em recintos de edificações visando o conforto dos usuários. Rio de Janeiro, Brazil: ABNT; 2000

13 Russo ICP. O papel da acústica das salas de aula na inteligibilidade da fala. In: Russo ICP, (org). Acústica e psicoacústica aplicadas à fonoaudiologia. São Paulo, Brazil: Lovise; 1999:213-221

14 Dantas MBS, Anjos CAL, Camboim ED, Pimentel MCR. Resultados de um programa de triagem auditiva neonatal em Maceió. Rev Bras Otorrinolaringol 2009;75(1):58-63

15 Folmer RL, Griest SE, Martin WH. Hearing conservation education programs for children: a review. J Sch Health 2002;72(2):51-57

16 Kujawa SG, Liberman MC. Acceleration of age-related hearing loss by early noise exposure: evidence of a misspent youth. J Neurosci 2006;26(7):2115-2123

17 BRASIL. Política Nacional de Atenção à Saúde Auditiva-PNASA. PORTARIA 2.073/GM, em 28 de setembro de 2004. Available on WWW.saude.org.br/pnasa Accessed in May, 2014.

18 BRASIL. Programa Saúde na Escola-PSE (Decreto n. 6286 de 05/12/ 2007. Available onWWW.saude.gov.br/portaldab/pse Accessed in April, 2014.

19 Lacerda ABM, Ribas A, Siqueira MMP. Triagem Auditiva Escolar: uma justificativa para sua realização. J Bras Fonoaudiol 2002; 3(12):229-232

20 Collela-Santos MF, Bragato GR, Martins PMF, Dias AB. A Triagem auditiva em escolares de 5 a 10 anos. Rev CEFAC 2009;11(4): 644-653

21 Oliveira RTO, Oliveira JP. A Triagem Auditiva Escolar enquanto instrumento de parceria entre a Saúde e a Educação. XI Congresso Nacional de Educação e III Encontro Sul Brasileiro de Psicopedagogia; 26-29 out 2009; Curitiba, Brazil: PUCPR; 2009

22 Howart LC. Coordinating a hearing health education program: challenges and strategies. Semin Hear 2008;29(1):111-121

23 Almeida Filho N, Filletti F, Guillaumon HR, Serafini F. Intensidade do ruído produzido em sala de aula e análise de emissões acústicas em escolares. Arq Int Otorrinolaringol 2012;16(1):91-95

24 Ribeiro MER, Oliveira RLS, Santos TMM, Scharlach RC. A percepção dos professores de uma escola particular de Viçosa sobre o ruído nas salas de aula. Rev. Equilíbrio Corporal e Saúde 2010;2(1):27-45

25 Couto MIV. Efeitos do ruído e da reverberação na discriminação auditiva em pré-escolares ouvintes. [Dissertação Mestrado]. São Paulo, Brazil: Pontifícia Universidade Católica; 1994

26 Rodrigues FOL. Triagem Auditiva em Crianças nas Escolas Públicas e Particulares. Monografia (Audiologia Clínica). Rio de Janeiro, Brazil: CEFAC; 1999

27 Fonseca V. Introdução as dificuldades de aprendizagem. Porto Alegre, Brazil: Artes Médicas; 1995

28 Vasconcelos RM, Monte MO, Aragão VMF, Silva BTF. Alterações auditivas em crianças de 7 a 9 anos de idade de uma escola publica de ensino fundamental em São Luís, Maranhão. Revista Brasileira em Promoção da Saude 2007;20(3):155-160

29 Jerger S, Jerger J. Alterações auditivas. São Paulo, Brazil: Atheneu; 1989

30 Russo IP. Audiologia Infantil. São Paulo, Brazil: Ed Cortês; 1994

31 Hidecker MJC. Noise-induced hearing loss in school-age children: what do we know? Semin Hear 2008;29(1):19-28

32 Heemann A, Heemann N. Natureza e percepção de valores. Rev Desenvolvimento e Meio Ambiente 2003;7:32-35

33 Goldblat D. Teoria Social e Ambiente. Lisbon, Brazil: Instituto Piaget; 1996

34 Giddens A. Modernidade e identidade. Rio de Janeiro, Brazil: Zahar Editores; 2002 